\title{
Jack Michonik: La descendencia. México: Plaza y Valdés, 2015.
}

\author{
Florinda F. Goldberg, Jerusalem
}

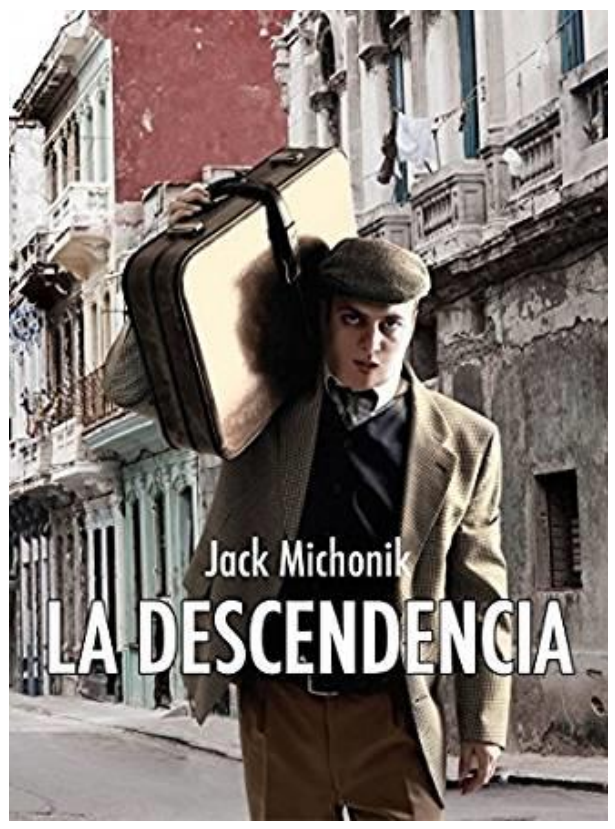

La descendencia de Jack Michonik se suma al corpus de la pequeña épica de la migración judía mediante las historias de tres jóvenes judíos que emigran de Europa oriental en la década de 1920, dos de ellos hacia América Latina, el tercero hacia Eretz Israel. Los avatares de sus viajes y sus adaptaciones a sus nuevos entornos se narran sobre el trasfondo de la historia general del pueblo judío hasta la década de 1960. Según su autor, la novela no se basa en biografías unitarias sino constituye un mosaico de situaciones típicas comunes a muchas historias migratorias.

La descendencia de Jack Michonik se suma al corpus de la pequeña épica de la migración judía mediante las historias de tres jóvenes judíos que emigran de Europa oriental en la década de 1920, dos de ellos hacia América Latina, el tercero hacia Eretz Israel. Los avatares de sus viajes y sus adaptaciones a sus nuevos entornos se narran sobre el trasfondo de la historia general del pueblo judío hasta la década de 1960. Según su autor, la novela no se basa en biografías unitarias sino constituye un mosaico de situaciones típicas comunes a muchas historias migratorias.

La narración se ocupa sobre todo de las trayectorias vitales de León y Jaime, quienes, casi por azar, terminan estableciéndose en la pequeña ciudad de Lárida, en la que es posible reconocer a la colombiana Cali. La novela acompaña el proceso de su afianzamiento económico, la formación de sus familias y su decisiva actuación en el establecimiento de la comunidad judía local, mediante un desarrollo novelístico clásico, con fuerte predominio del enfoque escénico en que sucesos y diálogos se desarrollan ante los ojos del lector. En cambio, la historia de Baruj es narrada y resumida por él mismo, en las cartas que envía a León desde su kibutz. La función de este tercer lado del triángulo es posibilitar un correlato entre la vida en la diáspora y la experiencia judía en Israel. 
El foco principal de la novela, sin embargo, no reside en los avatares de la inmigración (que ocupan dos tercios del relato) sino en el núcleo dramático que le da título y culminación: la descendencia, es decir, la posibilidad o imposibilidad de asegurar la continuidad del judaísmo en generaciones cuya identidad judía no se halla, como la de sus padres, afianzada por sus raíces en la vida comprehensivamente judía de las comunidades de Europa oriental.

La crisis sobreviene cuando David, el hijo de León, se enamora de una muchacha católica y decide convertirse y casarse por iglesia. Los esfuerzos de León por disuadirlo se estrellan contra la firmeza del joven enamorado. Profundamente dolorido, León termina aceptando lo que no puede impedir e inclusive asiste a la boda, ya que teme perder del todo a su hijo si adopta una oposición intransigente. Pero existen otros motivos para su resignación, que pueden inferirse de episodios anteriores en la novela, y en ellos reside la crítica de ésta respecto de la generación de inmigrantes. De hecho, un diálogo bastante anterior entre León y Jaime (270-271) evidencia que ambos prevén que el judaísmo de las futuras generaciones ha de diluirse inevitablemente (aunque sin imaginar que ello pueda ocurrir con sus propios hijos), pero no parecen dispuestos de actuar para evitarlo - o no saben cómo hacerlo.

Producida la crisis, León analiza sus conductas pasadas y comprende varias cosas. La primera, que su concentración en el progreso económico y en su propio prestigio dentro de la comunidad le impidió ocuparse de proveer a su hijo de contenidos judaicos que fueran más allá de las observancias básicas. También, que David recibió de él dobles mensajes: por una parte, la necesidad de mantener muy buenas relaciones con no judíos (sobre todo debido a sus intereses comerciales); por la otra, su decisión de que el adolescente recibiera la mejor educación accesible en la pequeña ciudad, para lo cual no vaciló en enviarlo a un colegio de curas.

Un motivo adicional, más íntimo y novelesco, justifica la resignación de León ante la decisión de su hijo. León ha estado enamorado toda su vida de una muchacha de su mismo shtetl; pero por timidez nunca hizo nada por realizar ese amor, tampoco en su vida adulta (y la gran ironía es que fue Jaime, su mejor amigo, quien se casó con ella). De alguna manera, León parece valorar en David esa capacidad de jugarse por amor de la que él careció.

En la defensa que hace David de su decisión, figura un curioso argumento en contra de la endosocialización como factor de fortalecimiento identitario: David sostiene que si eligiera como esposa 
a una de las jóvenes de la comunidad con las que se ha criado, sentiría que se estaba casando con una hermana...

El foco dramático en el tema de la descendencia es lo que otorga por contraste su importancia a la historia de Baruj. Al vivir en Israel, Baruj no enfrenta conflicto alguno respecto de la identidad judía de sus hijos y nietos. La tesis implícita en la novela es pues que, desaparecido el mundo judío tradicional, es imposible asegurar la continuidad del judaísmo fuera de Israel.

La última escena de la novela presenta esa tesis de manera simbólica. En mitad de la lujosa fiesta de bodas, León se refugia en un rincón del jardín para rumiar su frustración. A pocos pasos de él pero sin percibir su presencia, dos de sus amigos conversan entre sí, y uno de ellos afirma que con esa boda "se murió el judaísmo de nuestra descendencia" (389). En ese momento, una fina llovizna luminosa que ha acompañado místicamente todas las ceremonias fúnebres en la novela, comienza a descender lentamente sobre León...

Jaime Michonik nació en Ginebra, en una familia de judíos rusos; se crió en Bogotá y residió veinte años en Cali. Desde 1978 vive en Israel. Ha publicado cuatro novelas. La descendencia fue traducida al francés. 